\title{
Multiple Dimensions of Organizational Justice and Work-Related Outcomes among Health-Care Professionals
}

\author{
Urmila Rani Srivastava \\ Department of Psychology, Banaras Hindu University, Varanasi, India \\ Email: urbhu_24@yahoo.co.in
}

Received 30 September 2015; accepted 15 November 2015; published 18 November 2015

Copyright (C) 2015 by author and Scientific Research Publishing Inc.

This work is licensed under the Creative Commons Attribution International License (CC BY). http://creativecommons.org/licenses/by/4.0/

(c) (7) Open Access

\section{Abstract}

The notion of the fairness or justice has become an increasingly important construct in behaviour and management over the last two decades because of its serious personal and organizational consequences. Despite considerable research on job satisfaction and organizational commitment of employees, various types and forms of employees' justice perceptions have not been adequately examined. Studies of organizational justice in the area of health-care professionals are especially limited in the Indian setting. Because of higher expectations and demands on Indian hospitals, the issues of organizational justice and its associated work-related outcomes are quite relevant to employees working in them. With this background, the purpose of present study is to examine and compare the influence of different dimensions of organizational justice (of distributive, procedural, interpersonal (or relational), and informational justice) on work-related outcomes of job satisfaction and organizational commitment with special reference of healthcare professionals. Participants of the present study consisted of $\mathbf{1 0 0}$ health-care professional working in a government hospitals located in Varanasi (U.P., India). They were classified into three ranks: Doctors $(\mathrm{N}=36)$, Nurses $(\mathrm{N}=44)$, and Technicians and Hospital Administrative Staff $(\mathrm{N}=20)$ and were mainly recruited from four major clinical departments-cardiology, gastroenterology, obstetrics \& gynecology, and ENT. The statistical analyses of data included the descriptive statistics, coefficient of correlation and hierarchical regression analysis. The results of regression analysis revealed that among the four dimensions of justice, only procedural justice and relational justice significantly positively predicted job satisfaction of employees. Distributive and informational justice did not predict job satisfaction. Findings further indicated that informational justice was the only dimension that had significantly and positively predicted organizational commitment. Despite the significant zero-order correlations, distributive, procedural, interpersonal or relational justice did not predict organizational commitment. Implications of the study and avenues for future research were discussed. 


\section{Keywords}

\section{Distributive Justice, Procedural Justice, Interpersonal or Relational Justice, Informational Justice, Organizational Commitment and Job Satisfaction}

\section{Introduction}

The notion of the fairness or justice has become an increasingly important construct in behaviour and management over the last two decades because of its serious personal and organizational consequences [1]-[7]. Stimulated by studies conducted by Adams [8], organizational researchers have devoted considerable attention to the workplace fairness, as it is recognized as one of the major determinants of organizational effectiveness [4] [9]. The concepts of fairness or justice are very appropriate in the organizational environment as many procedures are implemented and many decisions are made regarding the distribution of outcomes [4].

Studies of organizational justice have illustrated that perceived fairness of rewards, organizational procedures and interpersonal treatment are related to individual attitudes and behaviours [10]. In spite of the four fold conceptualization of organizational justice, much of this research has not examined all four dimension of justice simultaneously.

The employees of the organization are influenced by the perceptions of fair treatment in many ways. Firstly, perceptions of fairness are illustrative of the fact that organizational authorities are [11] [12]. Secondly, a perception of fair treatment enhances employees' predictability and controllability for future events, thereby reducing the uncertainties of day to day working life. Lastly, perceptions of fair treatments indicate devotion to moral and ethical standards of the organization on the part of higher authorities.

This often gives the reason to employees to prefer to work for certain organization than others [13]-[15].

Study of employees' perceptions of the fairness of organizational processes is an outstanding issue for both scholars and practitioners as it influences many critical organizational outcomes. As organizational justice literature suggests, perceived fairness of rewards, decision-making procedures, and interpersonal treatment are found to be related to outcomes such as organizational commitment, job satisfaction, performance, employee's intention to stay and citizenship behaviors [1] [4] [16]. In this study, we aim to examine how organizational justice perceptions of employees have an influence on their job satisfaction and organizational commitment with special reference to applied research on health-care professionals. Although a great deal of research has addressed the issue of organizational justice, little empirical research has been conducted to examine the relationships among multiple dimensions of justice (distributive justice, procedural justice, and interpersonal and informational justice), job satisfaction and organizational commitment in the healthcare sector. Studies of organizational justice in the area of health-care professionals are especially limited in the Indian setting.

In India, employees in the health-care industry are facing extraordinary challenges and competitive pressures such as financial challenges, patient safety and security and quality. Aging populations, new therapeutic possibilities and rising expectations have made the health-care much more complex than in the past. As a result they have to cope with rapid advancements made in health-care sector as reflected in a staggering increase in medical knowledge, technologies, skills and resources, increasing specialization of health-care professionals and increasing patient demands. Mostly, Indian health-care employees work with in hospital cultures that orders that employees must strictly adhere to all policies and procedures for safety of patients and quality assurance. Because of higher expectations and demands on Indian hospitals, the issues of organizational justice and its associated work-related outcomes are quite relevant to employees working in them. Thus, in the present study, we have expanded the previous work on organizational justice with special reference to health-care professionals.

\subsection{Conceptional Framework}

People are social beings and devote considerable amount of time at their work place. Thus, organizations must create surroundings in which employees can to interact socially. One concept that is fundamental to human social interaction is justice. Whether, it is a promotion decision, the assignment of tasks, the allocation of rewards or simply any other type of social exchange, issues of fairness are bond to arise.

A widely used construct defining the quality of social interaction at work is organizational justice. Organiza- 
tional justice was the term coined by Greenberg [10] Organizational justice describes the individuals' (or groups) perception of the fairness of treatment received from an organization and their behavioral reaction to such perception. In other words, the term organizational justice refers to the extent to which employees are treated fairly at their workplace [17]-[19]. According to Foster [20], organizational justice refers to individual perceptions of fairness within organizations.

The principles of justice have long been recognized by social scientists as crucial for the functioning of organizations and personal satisfaction of individuals employed [21] [22]. As organizational injustice may lead to undesired organizational outcomes such as lower job satisfaction, retaliation, turnover, misbehavior, low productivity, and lower work commitment [19] [23]-[25], perceived fairness of rewards, decision-making procedures, and interpersonal treatment in an organization contributes to the development of high quality work relationships [16]

Despite the redundancy of studies in the field of justice in the last two decades, the valid theoretical data today mostly depends on the Equity Theory of Adams [26].

On the issues of justice, the equity theory of Adams [8] [26] has received the greatest attention from academicians and scientists in the field of HRM and organizational behavior [27]. This theory asserts that people develop perceptions of fairness by comparing ratio of their work inputs (effort) and outcome (i.e. rewards) to the corresponding ratios of a comparison other (e.g. a co-worker). If the comparative ratios perceived by the individual are unequal then inequity exists that lead to tension and distress felt by the individual. Brocker and Wiesenfeld [28] (1996) have illustrated three major impressions of theory and research in the justice literature.

1) Emphasis on equity theory and a focus on the perceived fairness of the work outcomes resulting from the social exchange relationship between employee and employer (i.e. distributive justice);

2) Interest in the perceived fairness of the ways by which organizations and their representatives make allocation decisions (i.e. procedural justice);

3) Highlighting on the interactive effects of distributive and procedural justice.

Earlier scholars have widely focused only on two types of distributive and procedural justice [10] [20] [29]. The clarity of the two-factor model of organizational justice clouded with the introduction of third type of justice i.e. interactional justice [30]-[32]. In his study, Colquitt [29] has suggested two aspects of interactional justice (interpersonal and informational). This study has very well supported the factor structures of organizational justice: distributive, procedural, interpersonal and informational justice as distinct dimensions. Although, distinction between procedural and distributive justice as distinct dimensions was well supported in the literature [23] [33]-[35], there is little agreement on the dimension of interactional justice. It is one of our goals to examine the empirical merit of the distinction among these three types of organizational justice.

\subsection{Concept of Distributive Justice}

Distributive justice is one of the oldest forms of justice and is a conceptualization based on the equity theory of Adams [8] [26]. It can be defined as perceived fairness and evaluation of decisional outcomes such as performance appraisal, pay, rewards and recognitions [9] [36]. Distributive justice is promoted where outcomes are consistent with implicit norms for allocation, such as equity or equality. Distributive injustices such as inequitable pay raises or unfair distributions of work load constitute what Lazarus and Launier [37] would characterize as harms or losses. Hence, to the extent distributive injustices constitute harms/losses and cause victims to doubt their capacity to cope adequately, employees" will regard distributive injustices as "stressors", which will in turn, produce psychological distress.

\subsection{Concept of Procedural Justice}

Procedural justice is the extent to which the dynamics of the decision process are judged to be fair. In other words, procedural justice involves the perceptions of fairness of organizational procedures by which outcomes are distributed or decisions are made [38]-[40]. According to Greenberg [10] procedural justice refers perceived fairness of policies and procedures used to make decisions in the work place. To the While distributive justice is concerned with the perceived fairness of outcomes, procedural justice is related with the perceived fairness of procedures used to make decisions and whether the procedure is considered to be reliable, transparent, ethical, free of bias, accurate, correctable and without deception [41]. Procedural justice is a perception that can be based on such aspects as whether the person is given a voice in the procedure and the decisions related to out- 
comes. Having voice in the procedure confirms the status of members and arouses trust in the decision-making system. This is especially important for weaker parties whose voices often go unheard [38]. Many empirical studies indicate that procedural justice has a significant impact on organizational attitudes and behaviors [1] [18] [42]-[45].

\subsection{Concept of Interactional/Relational Justice}

The literature on employee-employer relations shows that an employee expects the organization to treat him/her with respect, dignity, honesty and to extend equal treatment to all members [46] [47]. Bies and Moag [48] referred to this notion as interactional justice, which is the perception of the quality of treatment an employee receives when policies and procedures are implemented in the workplace. Interactional justice is defined as the interpersonal treatment people receive as procedures are enacted [48]. It pertains to the behavior of the organization's managers and higher authorities in carrying out their decisions, i.e., how they treat those who are subject to their authority, decisions, and actions. The major determinants of interactional justice include explanation, sensitivity consideration and empathy. Interactional justice is fostered when decision makers treat people with respect and sensitivity and explain the rationale for decisions thoroughly. Interactional justice involves perceptions of the fairness of the communication involved in organizational practices. Research reported by Bies and Moag [48] indicates appropriate justification of decisions (i.e. efforts to explain the results of decisions), honesty (i.e. avoidance of deception), propriety (i.e. absence of prejudicial statements and inappropriate questions), and respect (i.e. sincere and deferential treatment of individuals as well as the absence of personal attacks) are the four criteria that reveal the quality of treatment and are related to perceptions of interactional justice.

When individuals perceive they have been communicated with in a sensitive and respectful manner and are treated with politeness and dignity by those carrying out organizational procedures [1] [48], they are more likely to judge this communication as fair. The rationalization for interactional justice in the workplace is grounded in social exchange theory and norm of reciprocity [49]. From the social exchange perspective, employees expect fair, honest, polite, and truthful treatments from the organization and/or its authorities. Based on the norm of reciprocity, employees who perceive fair treatments by authorities are more likely to exhibit positive behaviours through greater commitments to goals of the organizations and by evidencing increased job satisfaction, organizational citizenship behaviors, improved job performances and reduced withdrawal behaviors [1] [4]. Of the three justice types, interactional justice has received the least attention [4]. Although some researchers have considered interactional justice as third type of justice [31] [32] [50], others have considered it a division of procedural justice [18] [51]. Greenberg [52] brought a new perspective to this debate by suggesting a four-factor structure of organizational justice. He suggested that the respect and sensitivity aspect of interactional justice might best be viewed as interpersonal facets of distributive justice because they alter reactions to decision outcomes (i.e. sensitivity can make feel better about unfavorable outcome). He further suggested that the explanation aspect of interactional justice might best be viewed as an informational facet of procedural justice because explanations often provide the information needed to evaluate structural aspects of the procedure. Interpersonal justice reflects the degree to which people are treated with politeness, dignity, and respect by authorities and third parties involved in executing procedures or determining outcomes [29].

\subsection{Concept of Informational Justice}

Informational justice is second new type of justice which focuses on explanations provided to people that convey information about why procedures were applied in a certain way or why outcomes were distributed in a certain manner [10] [53] [54]. In other words informational justice refers to the truthfulness and justification of information provided to employees. The appraisal that information is inadequate or untrue leads to the perceptions of injustice. Informational justice is thought to consist of factors that enhance individual perceptions of efficacy of explanations provided by the organizational agents. These factors include in reality information sharing about the organizational matters i.e. just keeping employees informed is often viewed by people as a fairness issue [55]. Other researchers believe that interactional justice consists of two distinct dimensions [53] [54]. The first dimension, interpersonal justice, corresponds to interpersonal behavior and refers to Bies and Moag's [48] concepts of respect and propriety. The second dimension, informational justice, relates to the explanations given to individuals for why certain procedures are implemented. Informational justice relates to the concepts of justification and honesty. 
Both this justice type gives origin to a new type of justice which is defined as Interactional justice.

It a very recent study, Colquitt [29], have supported four-factor structure of organizational justice as proposed by Greenberg [54] - distributive, procedural, interpersonal and informational justice as distinct dimensions, the author has also suggested that interpersonal and informational justice have received less attention than distributive and procedural justice, probably, as a result of their more recent appearance in the justice literature. Some recent research has shown their distinctive factor structures [1] [4] and differential predictive power regarding the personal and organizational outcomes [9] [23] [35] [56] [57]. These scholars have suggested that all the dimensions of justice should be treated as separate variables.

\subsection{Job Satisfaction}

Job satisfaction has been defined as connection between what one expects from job and what his perception about getting from job [58]. Job satisfaction has been extensively studied by researchers from last four decades. Job satisfaction is taken seriously based on assumption that higher job satisfaction lead to higher work performance [59].

Existence of job satisfaction is very important in a organization as it has significant impact in many fields like human resource management, behavior, Productivity, sociology, and strategic management etc. Job satisfaction is a measure of happiness of the workers with their job and working environment. That is why job satisfaction should exist wherever job occurs.

Locke [60] defined job satisfaction as "a pleasurable or positive emotional state resulting from the appraisal of one's job or job experiences". Job satisfaction is simply how people feel about their jobs and different aspects of their jobs. It is the extent to which people like (satisfaction) or dislike (dissatisfaction) their jobs [61]. Luthans [62] has documented that job satisfaction is an emotional response to job situation and is determined by how well the outcome meet or exceed expectations. Greenberg and Baron [63] defined job satisfaction as employees' cognitive, affective and evaluative reactions directed towards their job/work.

\subsection{Organizational Commitment}

The topic of organizational commitment is predominantly an important issue in today's highly competitive environment as business firms progressively rely more on their human resources [64]. Consequently, managers in organizations are constantly seeking ways to create greater commitment in employees [65] [66].

Organizational commitment is defined as "the relative strength of an individual's identification with and involvement in a particular organization" [67]. It is further conceptualized by the following three factors: "1) a strong belief in and acceptance of the organization's goals and values; 2) a willingness to exert considerable effort on behalf of the organization; 3) a definite desire to maintain organizational membership" [68]. Organizational commitment is a multi-dimensional construct. Meyer and Allen [69] and Dunham, Grube and Castaneda [70] identified three types of commitment: affective, continuance and normative commitment. Affective Commitment refers to Psychological attachment to organization. Employees with strong affective commitment stay in their organization because they want to. Continuance commitment refers to costs associated with leaving the organization. Individuals with strong continuance commitment stay because they need to do so. Normative Commitment refers to perceived obligation to remain with the organization Persons high in normative commitment stay because they feel that they ought to.

While researchers embrace diverse emphasis on the construct of organizational commitment, but most of them suggest that commitment represents both attitude that describes an individual's linkage to the organization and set behaviors by which individuals manifest that link.

\subsection{Importance of Studying of Job Satisfaction and Organizational Commitment of Health-Care Professionals}

The issue of job satisfaction is particularly relevant and of interest to health-care professionals due to the fact that employees' health and well-being depends a great deal on job satisfaction [71]. Job satisfaction should be an important concern for hospital employees because if they are dissatisfied they are not able to meet the demands of their patients. Health-care professionals who work in a profession that is extensively demanding and sometimes unpredictable can be susceptible to feelings of uncertainty and reduced job satisfaction. This is particularly 
important because employees in a healthcare sector are expected to provide high quality patient care while working in a highly stressful environment [72]. Job satisfaction is also an essential part of ensuring high quality healthcare. Dissatisfied health-care employees give poor quality and less efficient care. Studies have shown that job satisfaction in health-care settings has been found to have strong positive relationship with patient satisfaction. Hence, job satisfaction is an extremely important variable especially for health-care employees. Another outcome variable of this study is organizational commitment. Health-care organizational stability rests on organizational commitment. The levels and maintenance of organizational commitment is a major challenge for healthcare organizations. As the cost of health-care enhances, health-care employees are to perform predictable and quality patient care at lower cost. Research on organizational commitment is of importance to health-care organizations that strive for competitive advantage.

\section{Literature Review and Development of Hypotheses}

\subsection{Demographic Variables and Job Satisfaction and Organizational Commitment}

Several demographic variables (such as age, gender, marital status, salary, education \& length of service) commonly included in past studies of job satisfaction and organizational commitment have also been included in the present study. Studies have shown that age [73]-[75], gender and tenure [74] were found to be positively associated with organizational commitment. Mathieu and Zajac [73] have supported that older workers are more satisfied with their jobs show more commitments toward their organization and receive better hierarchical positions.

However, some studies have not found any relationship of age with organizational commitment [76]. Another demographic variable that has attracted the attention of researchers is the level of education. The findings regarding the relationship between level of education and organizational commitment have found to be mixed. In some studies level of education has reported to be negatively related with organizational commitment [73] [77] [78]. These authors have documented that highly educated employees have higher expectations from their employers. When they do not get adequate reward for their contributions their commitments toward the organization is diminished.

On the other hand, Sikorska-Simmons [79] found the level of education as one of the stronger predictors of organizational commitment among staff in assisted living. Findings showed that staff members who were more educated tended to report higher levels of commitment. Studies have further shown that organizational commitment was found to be positively related with job tenure [80] as employees have greater investments in their jobs. Findings further indicated the influence of gender on organizational commitment [73]. Studies have shown that men have reported higher level of organizational commitment than women [81]. Since women have to perform both work and family responsibilities hence, their commitments towards the organization tend to decline. The degree of an employee's commitment towards an organization also depends on the extent of pay and other financial and personal rewards. An organization which supports its employees mostly gets the desired feedback from the employees, where the employees feel an obligation to reciprocate by becoming more committed to their organization [82] [83].

A number of socio-demographic variables have been found to relate positively to job satisfaction. Results from several studies have indicated that there is a relationship between age and job satisfaction [73] [84] [85]. Despite the past researches, women have been found to report significantly higher job satisfaction than men [86] [87], even though this gender difference appears to be narrowing [88]. Regarding the relationship of education and job satisfaction Andrew [84] found that job satisfaction was higher for employees with lower level of education. In a recent study, Gurbuz [89] and Meagan, Kirk and Walter [90], level of education were positively related to their job satisfaction. Studies demonstrated that job tenure has been cited as a factor in job satisfaction [91]. Studies regarding the relationship between marital status and job satisfaction and organizational commitment are limited.

However, in one study Huey [92], has found the positive relationship between marital status and organizational commitment. Since, married employees have to look after their families they avoid taking the risks that are likely to make them lose their existing positions. The employees' fear about losing their jobs can be an indirect origin of a feeling of commitment [92]. Regarding the relationship between salary and job satisfaction, some studies noted that the level of the salary is a secondary variable and its influence may be limited when the work quality is unsatisfactory [93]. Brown et al. [93] had surveyed 16,266 employees working in more than 800 
institutions to determine the factors of happiness at work. The results indicated that the level of salary minimally influenced job satisfaction. Yet, when the researchers looked at an employee's worker's position in a company, they found a strong link with job satisfaction and concluded that rank increased happiness to a great extent when compared with higher salaries. In a similar study conducted on nurses, Shields and Ward [94] found that the lack of opportunities for career advancement or the possibility of promotion affect the job satisfaction of employees more than the size of the salary. Other studies indicated that salary raise can only influence jobs with low level income but not the high level ones and in some cases raise might have negative effect on job satisfaction.

In one study, Bender and Heywood [95] found that university professors who receive high income-in comparison with other jobs-have low job satisfaction because they think that PhD holders who work in industry earn more than them. In a study of extension agents, Scott, Swortzel and Taylor [96] have found that the effects of age, gender, and marital status on job satisfaction were non-significant. In the similar vein, Cano and Miller [97] in a sample of agricultural teachers found that selected demographic variables of age, years in current position, years of service, and degree status were not related with on job satisfaction.

The considerations put forward in the present section can be summarized in the following hypothesis:

H1. Job satisfaction will be affected by age, gender, marital status, salary, education and job tenure;

H2. Organizational commitment will be affected by age, gender, marital status, salary, education and job tenure.

\subsection{Relationship between Perceived Organizational Justice, Organizational Commitment and Job Satisfaction}

Over the years, academicians and scholars have seriously focused their attention in the study of organizational justice with the belief that enhanced perceptions of fairness can lead to outcomes important to organization. At the personal level, a perception of fairness satisfies an individual's needs for control, self-esteem, a sense of belonging, and ethical obligations. While at the organizational level, fairness provides legitimacy to management, thereby reducing counterwork behaviors, improving trust in authority, reducing fear of exploitation, and encouraging cooperation [98]. A stream of research has argued that various forms of organizational justice provide evidence for the value of perceived fairness of outcomes, decision making procedures and interpersonal treatment in determining an employee's expressions of job satisfaction, organizational commitment and job performance [1] [4] [18] [23] [24].

A number of researchers realized early the significance of equity considerations on allocations in organizations [26] [99]. Hence, most of the early research on organizational justice concentrated on pay inequity and its consequences. Such perceptions have been shown to result job dissatisfaction [35] [100] in poor performance [101] [102], organizational commitment, retaliation and involvement [103] [104]. In one study, Mcfarlin and Sweeney [24] reported that distributive justice was the stronger predictor of job satisfaction than with procedural justice. Realizing with the fact that job satisfaction is a multi-faceted phenomena studies have also shown the relationship between procedural justice and job satisfaction [43] [105]. Past researches showed that procedural justice also has a relationship with employee satisfaction [106]-[108], because when employees observe that performance rating and chances of promotion are not based on justice practices but on political and biased motives, and their performance is not truly considered, they become de-motivated and their satisfaction with job decreased. Organizational Justice as a source of motivation for employees is the existence of equitable distribution of rewards means when they observe rewards to be linked with level of work efforts, they feel satisfaction regarding working environment and co-workers which ultimately resulted in favorable attitude of employees towards work group and enhance their morale [109].

Research on organizational justice suggests that when an organization treats its employees fairly, employees are likely to reciprocate by adopting behaviors beneficial to the organization [110]. Scholars have repeatedly shown the connection between different forms of justice and organizational commitment from both a theoretical and an empirical standpoint. Initially, researchers have conceptualized fairness (justice) in terms of two broad categories: procedural justice (the fairness of the policies and procedures used to determine outcomes) and distributive justice (the fairness of the outcomes). In general, distributive justice may be a more important predictor of personal outcomes such as pay and job satisfaction, whereas procedural justice may have strong impact on organizational outcomes such as organizational commitment [18] [23] [24]. Research conducted over the past 
two decades indicates that perceived fairness of policies and procedures significantly affects employee attitudes behavior at work [38] [111]. A substantial body of research has shown that employees are more concerned with procedural justice (i.e. the fairness of the decision-making procedures) than with distributive justice [10] [17] [112] [113]. Likewise, Iqbal [114] also found that employees' perception of procedural justice has a great affect on their job satisfaction while distributive justice did not have any significant impact on job satisfaction.

An overarching and long-standing concern prevalent in the organizational justice literature was to study the beneficial effects of distributive and procedural justice only. This is because the notion of interactional justice has recently appeared in the literature. Hence, studies regarding the predictive effect of interactional justice over the effects of distributive and procedural justice are limited. However, very limited studies have shown the impact of interactional justice on organizational commitment and job satisfaction. Existing research on interactional justice has shown it to be positively related to employee performance, supervisor-directed citizenship behaviors, and job satisfaction [43]. In comparing the effects of different found that forms of organizational justice Masterson et al. [43] found that procedural justice is a stronger predictor of both organizational commitment and job satisfaction than interactional justice.

In a recent study on Iranian sport federations' employees Sareshkeh, Ghaziani, and Tayebi [115] found procedural justice has a direct effect on overall job satisfaction; and both distributive justice and interactional justice have a direct effect on overall organizational commitment; procedural justice as well as interactional justice have a direct effect on satisfaction with coworker and supervisor. Thus in view of the above mentioned discussion, we have proposed the following hypotheses:

H3. Employees' perceptions of distributive, procedural, interpersonal (or relational), and informational justice will be positively related to job satisfaction;

H4. Employees' perceptions of distributive, procedural, interpersonal (or relational), and informational justice will be positively related to organizational commitment;

Keeping in mind both research evidence and theory that supports the contribution of variables from each model in explaining job satisfaction and organizational commitment, a general hypothesis is also proposed:

H5. Variables from each model i.e. demographic variables in model-1 and organizational justice variables in model-2 (after controlling the effects of demographic variables) will be related to job satisfaction;

H6. Variables from each model i.e. demographic variables in model-1 and organizational justice variables in model-2 (after controlling the effects of demographic variables) will be related to organizational commitment.

\section{Methodology}

\subsection{Participants}

Participants of the present study consisted of 100 health-care professional working in a government hospitals located in Varanasi (U.P., India). Participants were classified into three ranks: Doctors $(\mathrm{N}=36)$, Nurses $(\mathrm{N}=$ 44), and Technicians and Hospital Administrative Staff $(\mathrm{N}=20)$ and were mainly recruited from four major clinical departments-cardiology, gastroenterology, obstetrics and gynecology, and ENT. The selection of participants was consistent with the ethical requirements for conducting research on human subjects. The employees who will have working experience of at least 5 years were eligible to participate in the study. Selected demographic variables were gathered and compiled. The characteristics of the sample were presented in Table 1 . In summary, the average age of the participants were $38.16(\mathrm{SD}=9.235)$, average tenure in the hospital and in the unit was 12.25 and $(\mathrm{SD}=8.81)$. Of the total sample $44 \%$ of the participants were male and $56 \%$ were female.

\subsection{Procedure}

Formal permission to conduct the study was obtained from the directors of hospital after explanation of the purpose of the study. Data were collected with the help of a self-administered questionnaire in English, together with a cover letter stating the purpose of the study. 156 questionnaires were distributed out of which 100 usable questionnaires were returned with a response rate of $64.1 \%$. The participants were assured about confidentiality of the data. They were also informed that the data will be used for academic purpose only.

The questionnaire included the measures of organizational justice, job satisfaction, organizational commitment and demographic information including participant's age, gender, marital status, job tenure, salary and educational qualification. All the completed questionnaires were kept confidential and examined only by the 
Table 1. Demographic characteristics of the sample.

\begin{tabular}{|c|c|c|}
\hline Variables & Number & Percentage \\
\hline \multicolumn{3}{|l|}{ Age (in years) } \\
\hline $24-35$ & 48 & $48 \%$ \\
\hline $36-45$ & 30 & $30 \%$ \\
\hline $46-55$ & 14 & $14 \%$ \\
\hline $56-60$ & 8 & $8 \%$ \\
\hline \multicolumn{3}{|l|}{ Gender } \\
\hline Male & 44 & $44 \%$ \\
\hline Female & 56 & $56 \%$ \\
\hline \multicolumn{3}{|l|}{ Marital status } \\
\hline Married & 76 & $76 \%$ \\
\hline Unmarried & 24 & $24 \%$ \\
\hline \multicolumn{3}{|c|}{ Salary in Rs. (per month) } \\
\hline$<20,000$ & 14 & $14 \%$ \\
\hline $20,000-40,000$ & 72 & $72 \%$ \\
\hline$>40,000$ & 14 & $14 \%$ \\
\hline \multicolumn{3}{|l|}{ Education } \\
\hline Post Graduate & 30 & $30 \%$ \\
\hline Graduate & 46 & $46 \%$ \\
\hline Undergraduate & 24 & $24 \%$ \\
\hline \multicolumn{3}{|c|}{ Length of service in years } \\
\hline Up to 10 & 54 & $54 \%$ \\
\hline $11-20$ & 26 & $26 \%$ \\
\hline $21-30$ & 12 & $12 \%$ \\
\hline $31-40$ & 8 & $8 \%$ \\
\hline \multicolumn{3}{|l|}{ Designation } \\
\hline Doctors & 36 & $36 \%$ \\
\hline Nurses & 44 & $44 \%$ \\
\hline Staff & 20 & $20 \%$ \\
\hline
\end{tabular}

researcher.

\subsection{Tools}

\subsubsection{Measurement of Organizational Justice}

Procedural and relational justice had been measured by 7 items and 6 items respectively as suggested by Elovainio, Kivimäki, and Vahtera [116]. The authors have adopted the items from Moorman [18] and reported the Cronbach's alpha coefficients of 0.90 and 0.81 for the scales of procedural and relational justice respectively. Distributive and informational justice had been measured by 4 items and 5 items respectively with the help of items taken from Bies and Moag [48]; and Shapiro, Buttner and Barry [117] as suggested by Colquitt [29]. The author has reported the Cronbach's alpha coefficients of 0.92 for the Distributive justice scale and 0.79 for informational justice scale. The scoring of all the justice items varied between 1 ("Strongly disagree") and 5 ("Strongly agree"). High scores on all the dimensions of organizational justice indicate higher perceptions of justice.

\subsubsection{Measurement of Organizational Commitment}

A fifteen-item version of the Organizational Commitment Questionnaire [118] was used to assess the degree of commitment one feels towards his/her organization. Out of 15 items, 9 items were true-keyed and 6 items were false-keyed. The response format was a 7-point Likert scale from 1 ("Strongly disagree") to 7 ("Strongly agree") for true-keyed items. For false-keyed items the pattern of scoring was reversed. The average of the 15 items was used as a global measure of organizational commitment. The researchers extensively use this scale since its development. The overall reliability of the scale found in this study was 0.76 (Cronbach's alpha). Because previous factor analytic result found only one underlying factor [118], the average of the 15 items was used a global measure of organizational commitment. 


\subsubsection{Job Satisfaction}

Job satisfaction would be assessed with the help of Brayfield-Rothe's [119] index of Job Satisfaction. This measure is a very popular tool for assessing an employee's level of job satisfaction, as it provides a quick measure of global job satisfaction. This is a 5 items scale scored on 7 point rating scale 1 (strongly disagree) to 7 (strongly agree). This measure has been used recently and was found to be very reliable [120] [121]. Judge, Bono and Locke [121] have reported Cronbach's alpha of .80 for this scale.

\subsection{Data Analysis}

The predictor variables for this study are: 1) procedural justice, 2) distributive justice, 3) interpersonal justice, and 4) informational justice. The criterion variables are: a) job satisfaction and b) commitment. The control variables are the demographic characteristics, which are: a) age, b) gender, c) marital status, d) salary, e) education and f) job tenure. In the present study, all the demographic variables that were assessed have been used. This is because they were related to several variables of interest. Rather than using none or some combination, they were all included in the analysis for simplicity. The data of the study were analyzed using, Descriptive statistics, correlation and hierarchical regression analyses. Hierarchical regression analyses were done in order to examine the contribution of each predictor variable in the explanation of criterion variable.

\section{Results}

Descriptive statistics such as mean, SD and range of scores was computed to describe the basic characteristics of the data (Table 2).

The results concerning $\mathrm{H} 1$ and $\mathrm{H} 2$ positing the relationships between demographic variables and job satisfaction and organizational commitment are displayed in Table 3 .

H1 of the study posited that job satisfaction will be affected by age, gender, marital status, salary, education and job tenure.

Table 2. Descriptive statistics of the study variables $(\mathrm{N}=100)$.

\begin{tabular}{ccccc}
\hline Variables & Minimum & Maximum & Mean & Std. deviation \\
\hline Age & 22.00 & 59.00 & 38.16 & 9.235 \\
Job tenure & 5.00 & 35.00 & 12.25 & 8.81 \\
Procedural justice & 12.00 & 35.00 & 26.13 & 4.73 \\
Relational justice & 13.00 & 28.00 & 22.012 & 3.43 \\
Distributional justice & 11.00 & 20.00 & 16.056 & 2.235 \\
Informational justice & 12.00 & 30.00 & 22.26 & 4.033 \\
Job satisfaction & 9.00 & 25.00 & 17.32 & 2.94 \\
Organizational commitment & 41.00 & 97.00 & 74.0200 & 14.09 \\
\hline
\end{tabular}

Table 3. Correlations between demographic variables and work-related outcomes (job satisfaction and organizational commitment).

\begin{tabular}{ccc}
\hline & Job satisfaction & Organizational commitment \\
\hline Age & 0.179 & $0.259^{* *}$ \\
Gender & $0.198^{*}$ & 0.016 \\
Marital Status & 0.083 & -0.155 \\
Salary & $-0.285^{* *}$ & $-0.214^{*}$ \\
Education & $-0.336^{* *}$ & $-0.272^{* *}$ \\
Job Tenure & 0.176 & 0.155 \\
\hline
\end{tabular}

\footnotetext{
${ }^{*} \mathrm{p}<0.05 ;{ }^{* *} \mathrm{p}<0.01$.
} 
It is evident from Table 3 that gender was found to be significantly positively associated with job satisfaction i.e. in the present study females were more satisfied with their jobs as compared to males. Education and salary were found to be significantly negatively associated with job satisfaction. However, age, marital status and job tenure were not related with job satisfaction. Likewise, $\mathbf{H 2}$ of the study stated that organizational commitment will be affected by age, gender, marital status, salary, education and job tenure. The results revealed that age was found to be significantly positively associated with organizational commitment. Education and salary were also found to be significantly negatively associated organizational commitment. Non-significant relationships of organizational commitment were found with gender, marital status and job tenure. These results thus, provided initial and partial support for support for $\mathbf{H 1}$ and $\mathbf{H} 2$.

Inspection of the correlational analyses depicted in Table 4 further indicated that all the correlations between justice variables (distributive, procedural, interpersonal or relational, and informational justice) and job satisfaction and organizational commitment were significant. The only relationship that was not significant was between distributive justice and job satisfaction.

Separate sets of hierarchical regression analyses were performed to test $\mathbf{H 3}$ and $\mathbf{H} 4$ of the study which posited that employees' perceptions of distributive, procedural, interpersonal (or relational), and informational justice will be positively related to job satisfaction and organizationalcommitment (Table 5). All the demographic variables were entered in the first step of the regression followed by various justice dimensions in the second step.

Regarding the third hypothesis, the results revealed that demographic variables explained $14.7 \%$ of variance $\left(\mathrm{F}_{6,93}=2.665, \mathrm{p}<0.05\right)$ in the prediction of job satisfaction. Education $(\beta=-0.261, \mathrm{p}<0.05)$ and salary $(\beta=-0.241$, $\mathrm{p}<0.05)$ were the only significant predictors of job satisfaction. Age, gender and job tenure did not predict job satisfaction.

The results further indicated that all the justice dimensions (distributive, procedural, interpersonal or relational, and informational justice) accounted for $38.3 \%$ of variance $\left(\mathrm{F}_{10,89}=10.143, \mathrm{p}<0.001\right)$ in the explanation of job satisfaction over and above the demographic variables. Among the four dimensions of justice, only procedural justice $(\beta=0.315, \mathrm{p}<0.05)$, and relational justice $(\beta=0.272, \mathrm{p}<0.05)$ significantly positively predicted job satisfaction of employees. Distributive $(\beta=-0.099, \mathrm{p}>0.05)$ and informational justice $(\beta=0.190, \mathrm{p}>0.05)$ did not predict job satisfaction.

Likewise in the prediction of organizational commitment, demographic variables accounted for $21.9 \%$ of variance $\left(\mathrm{F}_{6,93}=4.29, \mathrm{p}<0.01\right)$ at step-I. Among all the demographic variables, age $(\beta=0.508, \mathrm{p}<0.01)$, salary $(\beta=-0.232, \mathrm{p}<0.05)$ and education $(\beta=-0.396, \mathrm{p}<0.01)$, All the justice dimensions (distributive, procedural, interpersonal or relational, and informational justice) were added in the regression equation at step-II, and accounted for $28.4 \%$ of variance $\left(\mathrm{F}_{10,89}=8.902, \mathrm{p}<0.001\right)$ in prediction of organizational commitment over and above the demographic variables. It is interesting to note that informational justice was the only dimension that has significantly positively predicted organizational commitment $(\beta=0.413, \mathrm{p}<0.01)$, Despite the significant zero-order correlations, distributive $(\beta=-0.018, \mathrm{p}>0.05)$, procedural $(\beta=0.188, \mathrm{p}>0.05)$, interpersonal or relational justice $(\beta=-0.116, \mathrm{p}>0.05)$ did not predict organizational commitment. These results partially supported $\mathrm{H} 3$ and $\mathrm{H} 4$ of the study. Finally, $\mathrm{H} 5$ and $\mathrm{H} 6$ predicted that variables from each of the groups would be related to job satisfaction and organizational commitment. The findings again provide partial support for these hypotheses. At the Step-I, education and salary and at the Step-II procedural and interpersonal (or relational), were the only significant predictors of job satisfaction. Likewise, age, salary and education and informational justice were the significant predictors of organizational commitment at Step-I and Step-II respectively.

Table 4. Correlations between dimensions of organizational justice and work-related outcomes (job satisfaction and organizational commitment).

\begin{tabular}{ccc}
\hline $\begin{array}{c}\text { Organizational justice } \\
\text { dimensions }\end{array}$ & Job satisfaction & Organizational commitment \\
\hline Procedural justice & $0.600^{* *}$ & $0.542^{* *}$ \\
Relational justice & $0.590^{* *}$ & $0.515^{* *}$ \\
Distributional justice & 0.157 & $0.234^{*}$ \\
Informational justice & $0.621^{* *}$ & $0.622^{* *}$ \\
\hline
\end{tabular}

${ }^{*} \mathrm{p}<0.05 ;{ }^{* *} \mathrm{p}<0.01$. 
Table 5. Summary of hierarchical regression analysis predicting job satisfaction organizational commitment from organizational justice variables.

\begin{tabular}{|c|c|c|}
\hline Predictor variables & Job satisfaction & Organizational commitment \\
\hline Step I & Beta & Beta \\
\hline Age & 0.236 & $0.508^{* *}$ \\
\hline Gender & 0.037 & -0.082 \\
\hline Marital status & 0.019 & -0.106 \\
\hline Salary & $-0.249^{*}$ & $-0.232^{* *}$ \\
\hline Education & $-0.261^{*}$ & $-0.396^{* *}$ \\
\hline Length & -0.204 & -0.200 \\
\hline $\mathrm{R} 2$ & 0.147 & 0.219 \\
\hline \multicolumn{3}{|l|}{$\Delta \mathrm{R} 2$} \\
\hline $\mathrm{F}_{(6,93)}$ ratio & $2.665^{*}$ & $4.294^{* * *}$ \\
\hline \multicolumn{3}{|l|}{ Step II } \\
\hline Procedural justice & $0.315^{*}$ & 0.188 \\
\hline Distributive justice & -0.090 & -0.018 \\
\hline Informational justice & 0.190 & $0.413^{* *}$ \\
\hline Relational justice & $0.272^{*}$ & -0.016 \\
\hline $\mathrm{R} 2$ & 0.533 & 0.503 \\
\hline$\Delta \mathrm{R} 2$ & 0.386 & 0.284 \\
\hline $\mathrm{F}_{(10,89)}$ ratio & $10.143^{* * *}$ & $8.902^{* * *}$ \\
\hline
\end{tabular}

${ }^{*} \mathrm{p}<0.05 ;{ }^{* *} \mathrm{p}<0.01$.

\section{Discussion}

The major objective of this study was to examine effects of some selected demographic variables (such as age, gender, marital status, salary, education and length of service) and multiple dimensions of justice (distributive justice, procedural justice, interpersonal and informational justice) and two key organizational outcomes of job satisfaction and organizational commitment in a sample of healthcare employees. In general, we did not find much regarding the demographic predictions of job satisfaction and organizational commitment.

The results indicated that among demographic variables, education and salary were significantly and negatively job satisfaction and organizational commitment. The age of the employees, significantly and positively predicted organizational commitment. These findings can be explained by the fact that as the level of education and consequently, the salary of the employees increase, their areas of responsibilities also increase which result in low job satisfaction [84]. Likewise, the negative relationship of organizational commitment with education and salary found in the study corroborate with findings of Mathieu and Zajac [73], DeCotiis and Summers [77] and Mottaz [78]. These authors have documented that highly educated employees have higher expectations from their employers. When they do not get adequate reward or recognition for their contributions, their commitments toward the organization is diminished. The finding regarding the positive relationship between age and organizational commitment of the employees is consistent with the findings of (Mathieu and Zajac [73], Angel and Perry [74], Riordan, Griffith and Weatherly [75], and Nifadkar and Dongre [122]).

These studies suggest that older employees who have stayed with an organization for a prolonged period of time are likely to be emotionally attached to the organization show more commitments toward their organization and receive better hierarchical positions in their job. The effects of other demographic variables such as gender, marital status, and job tenure on these outcomes were found to be non-significant. This result is in line with those previous studies that also illustrated that most of the demographic variables are not significant predictors of organizational commitment [123]. Likewise, in a study of agricultural education teachers, Cano and Miller 
[97] have also found that selected demographic characteristics of age, years in current position, total years of teaching and degree status were not related to their overall level of job satisfaction. Scott, Swortzel and Taylor [96] reported the non-significant effect of age, marital status, and gender on job satisfaction. These inconsistent and mixed findings regarding the linkage between demographic variables and job satisfaction and organizational commitment should apply to the area in which the study was conducted. These results partially support $\mathrm{H} 1$ and $\mathrm{H} 2$ of the present study.

\subsection{Relationship between Perceived Organizational Justice and Job Satisfaction}

Despite the volume of empirical research that has investigated organizational justice most of the past research has focused mainly on the effects of distributive justice and procedural justice. Since, interactional justice has recently appeared in the literature therefore studies regarding its effect on different outcomes are limited [4]. Recently Greenberg [52] suggested that interactional justice further consisting of two specific types of interpersonal treatment i.e. interpersonal justice and informational justice. The interpersonal and informational justice has received less attention probably as a result of their more recent appearance in the justice literature.

Thus, another major objective of the study was to extend the field of organizational justice research by examining and testing hypothesized relationship between multiple dimensions of justice and multiple work-related outcomes in a single study.

H3 of the study posited that employees' perceptions of distributive, procedural, interpersonal (or relational), and informational justice will be positively related to job satisfaction. The results of regression analysis revealed that among the four dimensions of justice, only procedural justice and relational justice significantly positively predicted job satisfaction of employees. Distributive and informational justice did not predict job satisfaction. This result is in line with those from previous studies that also found that procedural justice would be a better predictor of job satisfaction, satisfaction to the organization and loyal behavior than distributive justice [23] [33] [115]. When the employees perceive managerial and organizational procedures such as distribution of rewards, selection and decision making fairly, their level of satisfaction enhances. The positive emotion of individuals toward procedural justice brings about higher levels of satisfaction. Findings further revealed that interpersonal or relational justice was another significant predictor of job satisfaction. Interpersonal justice corresponds to interpersonal behavior and is fostered when decision makers treat people with respect, sensitivity and propriety [48]. Generally, people are more accepting of decisions that result from fair procedures than with decisions that result from unfair procedures. Moreover, people who accept organizational decisions tend to cooperate with authority figures [17] [39]. The rationalization for interactional justice in the workplace is grounded in social exchange theory and norm of reciprocity [49]. From the social exchange perspective, employees expect fair, honest, polite, and truthful treatments from the organization and/or its authorities. Based on the norm of reciprocity, employees who perceive fair treatments by authorities are more likely to exhibit increased job satisfaction as sensitivity can make feel better even about unfavorable outcome. When the expectation of an employee is met, he or she is more likely to reciprocate the fair treatment received from the supervisors by developing a positive affective feeling towards his/her job. Studies have indicated that employee satisfaction is enhanced when there is interactional fairness in the workplace [1] [4] [29]. The results corroborate with a very recent study conducted by Iqbal [114] in the Pakistan context who also found that employees' perception of procedural justice has a great influence on their job satisfaction while distributive justice did not have any significant impact on job satisfaction.

The findings further illustrated that in the prediction of health-care employees job satisfaction distributive justice has not played any significant role. This finding conflicted with the prior studies of Cropanzano and Greenberg [9], Folger and Konovsky [23], and McFarlin and Sweeney [24]. This result may be partially due to sample-spe- cific attributes and relationships. Health-care organizations are characterized as highly information centric business areas. Most of the health-care employees are highly skilled and knowledgeable. This results in large numbers of well paid jobs in health-care organizations. Consequently they are not bothered much about the fairness regarding the allocation of outcomes. In the Asian context, Yoon [124] has illustrated that procedural justice and equity status had more effect on job satisfaction than distributive justice.

Further according to Yoon [124], the Asian societies are more concerned with aspects such as social harmony, relational norms and collective values compared to Western societies. This is because collectively oriented societies prefer to have the equality principle and need-based distribution rule of rewards while individualistic 
oriented societies prefer to have the contribution-based equity principle [125]. In conclusion, the results of the study did not support the general conclusion of justice literature that distributive justice is predictive of specific attitudes about the particular outcomes in question, whereas procedural justice has particularly strong impacts on attitudes about institutions or authorities such as organizational commitment or trust in management [17] [23]. Several scholar have documented that Procedural justice correspond to the organizational, while the international justice corresponded to the supervisor [14] [43]. Further, procedural justice is seen as more strategic than distributive justice as determines the outcomes. These results partially supported $\mathrm{H} 3$ of the study.

\subsection{Relationship between Perceived Organizational Justice and Organizational Commitment}

H4 of the study stated that employees' perceptions of distributive, procedural, interpersonal (or relational), and informational justice will be positively related to organizational commitment. It is interesting to note that informational justice was the only dimension that has significantly positively predicted organizational commitment. Despite the significant zero-order correlations, distributive, procedural, interpersonal or relational justice did not predict organizational commitment. These results partially supported $\mathrm{H} 4$ of the study. Similar to the findings of the present study, Imberman [126] also found that informational justice explained unique variance in affective commitment above and beyond all the dimensions of justice.

Informational justice is thought to consist of factors that enhance individual perceptions of efficacy of explanations provided by organizational agents. These factors include perception of organizational agents' truthfulness and justification. The link between informational justice and organizational commitment can be explained by the fact that when higher authorities and managers keep informed their employees about organizational matters, they tend to inspire feelings of loyalty and voluntary compliance of policies and rules among their employees thus fostering theirorganizational commitment.

Lavelle and colleagues explain the link between organizational justice and commitment in terms of social exchange [127]. Beyond short-term and impersonal economic exchanges, long-term exchanges, in which the fate of the other party has real importance, punctuate our social life [49]. Thus, if we feel that we are being treated fairly by an organization, we believe that the organization is looking after us [128]. Through reciprocity, we provide our commitment in exchange for this perception of fair treatment from the organization. This positive link between the various forms of organizational justice and organizational commitment has been confirmed by a plethora of empirical studies that have been reviewed in meta-analytic studies on organizational justice [1] [4]. Thus, we can assume that positive connections exist between individual-level justice perceptions and the degree of individual-level organizational commitment.

\section{Contributions, Implications, Limitations, and Future Research Suggestions}

Despite considerable research on job satisfaction and organizational commitment of employee, various types and forms of employees' justice perceptions have not been adequately examined. In conclusion, the primary contribution of the present study to the existing literature is its empirical testing regarding the comparison of the impact of various dimensions of justice to predict two important work-related outcomes i.e. job satisfaction and organizational commitment.

The results revealed that procedural justice and relational justice were important predictors of job satisfaction and that informational justice was the only significant predictor of organizational commitment of employees. Therefore, managers must take notice of the employees' perceptions of justice within the organization. They should be trained to enhance employees' perceptions of interactional fairness through planned policies and initiatives that recognize the worth of employees and treat them with respect and dignity. The study results indicate that practitioner should be aware of how procedural justice and interpersonal justice have an influence on job satisfaction and they must be careful to use these elements more efficiently and strategically. With special reference to health-care employees, the higher authorities in health-care organizations have to become aware of the extent that their decisions and methods of making decisions influence the satisfaction and commitment of their staff which may in turn influence their quality of patient care.

Despite these contributions, this study also has certain limitations. This study is based on a single occupation of health-care professionals; hence the working context of the participants may limit the results of being generalized to other occupation. Hence, the current findings should be tested in different public and private sectors in- 
cluding education, hospitality, manufacturing etc.

\section{References}

[1] Cohen-Charash, Y. and Spector, P.E. (2001) The Role of Justice in Organization: A Meta-Analysis. Organizational Behavior and Human Decision Processes, 86, 278-321. http://dx.doi.org/10.1006/obhd.2001.2958

[2] Cropanzano, R. and Schminke, M. (2001) Using Social Justice to Build Effective Work Groups. In: Turner, M., Ed., Groups at Work: Advances in Theory and Research, Erlbaum, Hillsdale, 143-171.

[3] Elovainio, M., Kivimäki, M. and Helkama, K. (2001) Organizational Justice Evaluations, Job Control and Occupational Strain. Journal of Applied Psychology, 86, 418-424. http://dx.doi.org/10.1037/0021-9010.86.3.418

[4] Colquitt, J.A., Conlon, D.E., Wesson, M.J., Porter, C.O.L.H. and Ng, K.Y. (2001) Justice at the Millennium: A MetaAnalytic Review of 25 Years of Organizational Justice Research. Journal of Applied Psychology, 86, 425-445. http://dx.doi.org/10.1037/0021-9010.86.3.425

[5] Colquitt, J.A. and Greenberg, J. (2003) Organizational Justice: A Fair Assessment of the State of the Literature. In: Greenberg, J., Ed., Organizational Behavior: The State of the Science, Lawrence Erlbaum Associate, Inc., Mahwah, $165-210$.

[6] Ebeulin, R.J. and Tatum, B.C. (2008) Making Just Decisions: Organizational Justice, Decision Making, and Leadership. Management Decision, 46, 310-329. http://dx.doi.org/10.1108/00251740810854177

[7] Bolat, O.I. (2010) The Relationships between Leader-Member Exchange and Organizational Justice in Hotels. European Journal of Economics, Finance and Administrative Sciences, 26, 115-125.

[8] Adams, J.S. (1963) Toward an Understanding of Inequity. Journal of Abnormal and Social Psychology, 67, $422-436$. http://dx.doi.org/10.1037/h0040968

[9] Cropanzano, R. and Greenberg, J. (1997) Progress in Organizational Justice: Tunneling through the Maze. In: Cooper, C.L. and Robertson, I.T., Eds., International Review of Industrial and Organizational Psychology, Vol. 12, John Wiley \& Sons, New York, 317-372.

[10] Greenberg, J. (1990) Organizational Justice: Yesterday, Today, and Tomorrow. Journal of Management, 16, $399-432$. http://dx.doi.org/10.1177/014920639001600208

[11] Lind, E.A. (2001) Fairness Heuristic Theory: Justice Judgments as Pivotal Cognitions in Organizational Relations. In: Greenberg, J. and Cropanzano, R., Eds., Advances in Organizational Justice, Stanford University Press, Stanford, 5688.

[12] Van den Bos, K. (2001) Uncertainty Management: The Influence of Uncertainty Salience on Reactions to Perceived Procedural Fairness. Journal of Personality and Social Psychology, 80, 931-941. http://dx.doi.org/10.1037/0022-3514.80.6.931

[13] Cropanzano, R., Byrne, Z.S., Bobocel, D.R. and Rupp, D.R. (2001) Moral Virtues, Fairness Heuristics, Social Entities, and Other Denizens of Organizational Justice. Journal of Vocational Behavior, 58, 164-209. http://dx.doi.org/10.1006/jvbe.2001.1791

[14] Cropanzano, R., Rupp, D.E., Mohler, C.J. and Schminke, M. (2001) Three Roads to Organizational Justice. In: Ferris, J., Ed., Research in Personnel and Human Resources Management, Vol. 20, JAI Press, Greenwich, 1-113. http://dx.doi.org/10.1016/s0742-7301(01)20001-2

[15] Folger, R. (1998) Fairness as Moral Virtue. In: Schminke, M., Ed., Managerial Ethics: Moral Management of People and Processes, Erlbaum, MahWah, 13-34.

[16] Erdogan, B., Liden, R.C. and Kraimer, M.L. (2006) The Moderating Role of Organizational Culture. Academy of Management Journal, 49, 395-406. http://dx.doi.org/10.5465/AMJ.2006.20786086

[17] Lind, E.A. and Tyler, T.R. (1988) The Social Psychology of Procedural Justice. Plenum Press, New York. http://dx.doi.org/10.1007/978-1-4899-2115-4

[18] Moorman, R.H. (1991) Relationship between Organizational Justice and Organizational Citizenship Behaviors: Do Fairness Perceptions Influence Employee Citizenship? Journal of Applied Psychology, 76, 845-855. http://dx.doi.org/10.1037/0021-9010.76.6.845

[19] Heponiemi, T., Elovainio, M., Laine, J., Pekkarinen, L., Eccles, M., Noro, A., Soveri, F.H. and Sinervo, T. (2007) Productivity and Employees' Organizational Justice Perceptions in Long-Term Care for the Elderly. Research in Nursing \& Health, 30, 498-507. http://dx.doi.org/10.1002/nur.20205

[20] Foster, R.D. (2010) Resistance, Justice, and Commitment to Change. Human Resources Development Quarterly, 21, 3 39. http://dx.doi.org/10.1002/hrdq.20035

[21] Moore, B.J. (1978) Injustice: The Social Bases of Obedience and Revolt. M. E. Sharpe, White Plains. 
[22] Okun, A.M. (1975) Equality and Efficiency: The Big Tradeoff. Brookings Institution, Washington DC.

[23] Folger, R. and Konovsky, M.A. (1989) Effects of Procedural and Distributive Justice Reactions to Pay Raise Decisions. Academy of Management Journal, 32, 115-130. http://dx.doi.org/10.2307/256422

[24] McFarlin, D.B. and Sweeney, P.D. (1992) Distributive and Procedural Justice as Predictors of Satisfaction with Personal and Organizational Outcomes. Academy of Management Journal, 35, 626-637. http://dx.doi.org/10.2307/256489

[25] Martinson, B.C., Anderson, M.S., Crain, A.L. and De Vries, R. (2006) Scientists' Perceptions of Organizational Justice and Self-Reported Misbehaviors. Journal of Empirical Research and Human Research Ethics, 1, 51-66.

[26] Admas, J.S. (1965) Inequity in Social Exchange. In: Berkowitz, L., Ed., Advances in Experimental Social Psychology, Volume 2, Academic Press, New York, 267-299. http://dx.doi.org/10.1016/s0065-2601(08)60108-2

[27] Mowday, R.T. (1967) Equity Theory: Predictions of Behavior in Organizations. In: Steers, R.M. and Porter, L.W., Eds., Motivation \& Work Behavior, 4th Edition, Mcgraw-Hill, New York, 89-110.

[28] Brockner, J. and Wiesenfeld, B.M. (1996) An Integrative Framework for Explaining Reactions to Decisions: Interactive Effects of Outcomes and Procedures. Psychological Bulletin, 120, 189-208. http://dx.doi.org/10.1037/0033-2909.120.2.189

[29] Colquitt, J.A. (2001) On the Dimensionality of Organizational Justice: A Construct Validation of a Measure. Journal of Applied Psychology, 86, 386-400. http://dx.doi.org/10.1037/0021-9010.86.3.386

[30] Barling, J. and Phillips, M. (1993) Interactional, Formal, and Distributive Justice in the Workplace: An Exploratory Study. The Journal of Psychology, 127, 649-656. http://dx.doi.org/10.1080/00223980.1993.9914904

[31] Aquino, K. (1995) Relationships among Pay Inequity, Perceptions of Procedural Justice, and Organizational Citizenship. Employee Responsibilities and Rights Journal, 8, 21-33. http://dx.doi.org/10.1007/BF02621253

[32] Skarlicki, D.P. and Folger, R. (1997) Retaliation in the Workplace: The Roles of Distributive, Procedural, and Interactional Justice. Journal of Applied Psychology, 82, 434-443. http://dx.doi.org/10.1037/0021-9010.82.3.434

[33] Alexander, S. and Ruderman, M. (1987) The Role of Procedural and Distributive Justice in Organizational Behavior. Social Justice Research, 1, 177-198. http://dx.doi.org/10.1007/BF01048015

[34] Gilliland, S.W. (1994) Effects of Procedural and Distributive Justice on Reactions to a Selection System. Journal of Applied Psychology, 79, 691-701. http://dx.doi.org/10.1037/0021-9010.79.5.691

[35] Sweeney, P.D. and McFarlin, D.B. (1993) Workers' Evaluations of the "Ends" and the "Means": An Examination of Four Models of Distributive and Procedural Justice. Organizational Behavior and Human Decision Processes, 55, 2340. http://dx.doi.org/10.1006/obhd.1993.1022

[36] Byrne, Z.S. and Cropanzano, R. (2001) The History of Organizational Justice: The Founders Speak. In: Cropanzano, R., Ed., Justice in the Workplace: From Theory to Practice, Vol. 2, Lawrence Erlbaum Associates, Inc., Mahwah, 3-26.

[37] Lazarus, R.S. and Launier, R. (1978) Stress-Related Transactions between Person and Environment. In: Pervin, L.A. and Lewis, M., Eds., Perspectives in Interactional Psychology, Plenum, New York, 287-327. http://dx.doi.org/10.1007/978-1-4613-3997-7 12

[38] Thibaut, J. and Walker, L. (1975) Procedural Justice: A Psychological Analysis. Lawrence Erlbaum Associates, Hillsdale.

[39] Lind, E.A. (1995) Justice and Authority Relations in Organizations. In: Cropanzano, R.S. and Kacmar, K.M., Eds., Organizational Politics, Justice, and Support: Managing the Social Climate of the Workplace, Quorum Books, Westport, 83-96.

[40] Kim, W.C. and Mauborgne, R.A. (1998) Procedural Justice, Strategic Decision Making, and the Knowledge Economy. Strategic Management Journal, 19, 323-338. http://dx.doi.org/10.1002/(SICI)1097-0266(199804)19:4<323::AID-SMJ976>3.0.CO;2-F

[41] Leventhal, G.S. (1980) What Should Be Done with Equity Theory? In: Gergen, K.J., Greenberg, M.S. and Willis, R.H., Eds., Social Exchanges: Advances in Theory and Research, Plenum, New York, 27-55. http://dx.doi.org/10.1007/978-1-4613-3087-5_2

[42] Brockner, J. (1994) Perceived Fairness and Survivors Reactions to Layoffs, or How Downsizing Organizations Can Do Well by Doing Good. Social Justice Research, 7, 345-363. http://dx.doi.org/10.1007/BF02334861

[43] Masterson, S.S., Lewis, K., Goldman, B.M. and Taylor, M.S. (2000) Integrating Justice and Social Exchange: The Differing Effects of Fair Procedures and Treatment of Work Relationships. Academy of Management Journal, 43, 738748. http://dx.doi.org/10.2307/1556364

[44] Rupp, D.E. and Cropanzano, R. (2002) The Mediating Effects of Social Exchange Relationships in Predicting Workplace Outcomes from Multifoci Organizational Justice. Organizational Behavior and Human Decision Processes, 89, 925-946. http://dx.doi.org/10.1016/S0749-5978(02)00036-5

[45] Lavelle, J.J., Brockner, J., Konovsky, M.A., Price, K.H., Henley, A.B., Taneja, A. and Vinekar, V. (2009) Commit- 
ment, Procedural Fairness, and Organizational Citizenship Behavior: A Multifoci Analysis. Journal of Organizational Behavior, 30, 337-357. http://dx.doi.org/10.1002/job.518

[46] Janssens, M., Sels, L. and Van den Brande, I. (2003) Multiple Types of Psychological Contracts: A Six-Cluster Solution. Human Relations, 56, 1349-1378. http://dx.doi.org/10.1177/00187267035611004

[47] Kickul, L. and Liao-Troth, M.A. (2003) The Meaning behind the Message: Climate Perceptions and the Psychological Contract. Mid-American Journal of Business, 18, 23-32. http://dx.doi.org/10.1108/19355181200300009

[48] Bies, R.J. and Moag, J.S. (1986) Interactional Justice: Communication Criteria for Justice. In: Sheppard, B., Ed., Research on Negotiation in Organizations, Volume 1, JAI Press, Greenwich, 43-55.

[49] Cropanzano, R. and Mitchell, M.S. (2005) Social Exchange Theory: An Interdisciplinary Review. Journal of Management, 31, 874-900. http://dx.doi.org/10.1177/0149206305279602

[50] Tata, J. and Bowes-Sperry, L. (1996) Emphasis on Distributive, Procedural, and Interactional Justice: Differential Perceptions of Men and Women. Psychological Reports, 79, 1327-1330. http://dx.doi.org/10.2466/pr0.1996.79.3f.1327

[51] Niehof, B.P. and Moorman, R.H. (1993) Justice as a Moderator of the Relationship between Methods of Monitoring and Organizational Citizenship Behavior. Leadership of Management Journal, 36, 527-556.

[52] Greenberg, J. (1996) The Quest for Justice on the Job. Sage, Thousand Oaks.

[53] Greenberg, J. (1993) Stealing in the Name of Justice: Informational and Interpersonal Moderators of Theft Reactions to Underpayment Inequity. Organizational Behavior and Human Decision Processes, 54, 81-103. http://dx.doi.org/10.1006/obhd.1993.1004

[54] Greenberg, J. (1993) The Social Side of Fairness: Interpersonal and Informational Classes of Organizational Justice. In: Cropanzano, R., Ed., Justice in the Workplace: Approaching Fairness in Human Resource Management, Lawrence Erlbaum Associates, Hillsdale, 79-103.

[55] Bies, R.J. (2001) International (In)justice: The Sacred and the Profane. In: Greenberg, J. and Cropanzano, R., Eds., Advances in Organization Justice, Stanford University Press, Palo Alto, 89-118.

[56] Chory-Assad, R.M. (2002) Classroom Justice: Perceptions of Fairness as a Predictor of Student Motivation, Learning, and Aggression. Communication Quarterly, 50, 58-77. http://dx.doi.org/10.1080/01463370209385646

[57] Chory-Assad, R.M. and Paulsel, M.L. (2004) Classroom Justice: Student Aggression and Resistance as Reactions to Perceived Unfairness. Communication Education, 53, 253-273. http://dx.doi.org/10.1080/0363452042000265189

[58] Lock, A.E. (1996) What Is Job Satisfaction? Organization Behavior and Human Performance. Academy of Management, 4, 309-414.

[59] Yang, S.-B., Brown, G.C. and Moon, B. (2011) Factors Leading to Corrections Officers Job Satisfaction. Public Personnel Management, 40, 359-369. http://dx.doi.org/10.1177/009102601104000407

[60] Locke, E.A. (1976) The Nature and Causes of Job Satisfaction. In: Dunnette, M.D., Ed., Handbook of Industrial and Organizational Psychology, McGraw Hill, New York, 1297-1349.

[61] Spector, P.E. (1997) Job satisfaction: Application, Assessment, Causes, and Consequences. Sage, Thousand Oaks.

[62] Luthans, F. (1998) Organizational Behavior. 8th Edition, Irwin McGraw-Hill, Boston.

[63] Greenberg, J. and Baron, R.A. (2000) Behavior in Organizations. Seventh Edition, Prentice Hall, Upper Saddle River.

[64] Kleinman, G., Siegel, P.H. and Eckstein, C. (2001) Mentoring and Learning: The Case of CPA Firms. Leadership and Organization Development Journal, 22, 22-34. http://dx.doi.org/10.1108/01437730110380192

[65] Limerick, D., Cunnington, B. and Crowther, F. (1998) Managing the New Organization. Business \& Professional Publishing, Sydney.

[66] Nadler, D. (1997) Champions of Change. Jossey-Bass, New York.

[67] Mowday, R.T. (1998) Reflections on the Study and Relevance of Organizational Commitment. Human Resource Management Review, 8, 387-401. http://dx.doi.org/10.1016/S1053-4822(99)00006-6

[68] Porter, L.W., Steers, R.M., Mowday, R.T. and Boulian, P.V. (1974) Organizational Commitment, Job Satisfaction, and Turnover among Psychiatric Technicians. Journal of Applied Psychology, 59, 603-609. http://dx.doi.org/10.1037/h0037335

[69] Meyer, J.P. and Allen, N.J. (1991) A Three-Component Conceptualization of Organizational Commitment. Human Resource Management Review, 1, 61-89. http://dx.doi.org/10.1016/1053-4822(91)90011-Z

[70] Duham, R., Grube, J. and Castaneda, M. (1994) Organizational Commitment, the Unity of an Integrative Definition. Journal of Applied Psychology, 79, 370-380. http://dx.doi.org/10.1037/0021-9010.79.3.370

[71] Adams, K.L., Daley, D.O., Qiu, Y.-L., Whelan, J. and Palmer, J.D. (2000) Repeated, Recent and Diverse Transfers of a Mitochondrial Gene to the Nucleus in Flowering Plants. Nature, 408, 354-357. http://dx.doi.org/10.1038/35042567 
[72] Arnetz, J.E. and Arnetz, B.B. (2000) Implementation and Evaluation of a Practical Intervention Programme for Dealing with Violence towards Health Care Workers. Journal of Advanced Nursing, 31, 668-680. http://dx.doi.org/10.1046/j.1365-2648.2000.01322.x

[73] Mathieu, J.E. and Zajac, D.M. (1990) A Review and Meta-Analysis of the Antecedents, Correlates and Consequences of Organizational Commitment. Psychological Bulletin, 108, 171-194. http://dx.doi.org/10.1037/0033-2909.108.2.171

[74] Angel, H.L. and Perry, J.L. (1981) An Assessment of Organizational Commitment and Organizational Effectiveness. Administrative Science Quarterly, 26, 1-13. http://dx.doi.org/10.2307/2392596

[75] Riordan, C.M., Griffith, R.W. and Weatherly, E.W. (2003) Age and Work-Related Outcomes: The Moderating Effects of Status Characteristics. Journal of Applied Social Psychology, 33, 37-57. http://dx.doi.org/10.1111/j.1559-1816.2003.tb02072.x

[76] Iqbal, A. (2010) An Empirical Assessment of Demographic Factors, Organizational Ranks and Organizational Commitment. International Journal of Business and Management, 5, 16-27. http://dx.doi.org/10.5539/ijbm.v5n3p16

[77] DeCotiis, T.A. and Summers, T.P. (1987) A Path Analysis of a Model of the Antecedents and Consequences of Organizational Commitment. Human Relations, 40, 445-470. http://dx.doi.org/10.1177/001872678704000704

[78] Mottaz, C.J. (1988) Determinants of Organizational Commitment. Human Relations, 41, 467-482. http://dx.doi.org/10.1177/001872678804100604

[79] Sikorska-Simmons, E. (2005) Predictors of Organizational Commitment among Staff in Assisted Living. The Gerontologist, 45, 196-205. http://dx.doi.org/10.1093/geront/45.2.196

[80] Salancik, G. (1977) Commitment and the Control of Organizational Behavior and Belief. In: Staw, B. and Salancik, G., Eds., New Directions in Organizational Behavior, St. Clair Press, Chicago, 1-54.

[81] Lim, T. (2003) Relationship among Organizational Commitment, Learning Organizational Culture and Job Satisfaction in One Korean Private Organization. Dissertation Abstracts International, 64, Article ID: 2008A.

[82] Folger, R. and Cropanzano, R. (1998) Organizational Justice and Human Resource Management. Sage, Thousand Oaks.

[83] Meyer, J. and Allen, N. (1997) Commitment in the Workplace: Theory, Research, and Application. Sage Publications, Thousand Oaks.

[84] Andrew, E.C. (1996) Job Satisfaction. British Journal of Industrial Relations, 7, 189-216.

[85] Nadiri, H. and Tanova, C. (2010) An Investigation of the Role of Justice in Turnover Intentions, Job Satisfaction, and Organizational Citizenship Behavior in Hospitality Industry. International Journal of Hospitality Management, 29, 3341. http://dx.doi.org/10.1016/j.ijhm.2009.05.001

[86] Hull, K. (1999) The Paradox of the Contented Female Lawyer. Law and Society Review, 33, 687-702. http://dx.doi.org/10.2307/3115108

[87] Okpara, J.O. (2004) Personal Characteristics as Predictors of Job Satisfaction. Information Technology \& People, 17, 327-338. http://dx.doi.org/10.1108/09593840410554247

[88] Rose, M. (2005) Job Satisfaction in Britain: Coping with Complexity. British Journal of Industrial Relations, 43, 455467. http://dx.doi.org/10.1111/j.1467-8543.2005.00364.x

[89] Gurbuz, A. (2007) An Assessment on the Effect of Education Level on the Job Satisfaction from the Tourism Sector Point of View. Master's Thesis, Doğuş Üniversitesi Dergisi, Dergi adı.

[90] Meagan, S., Kirk, A.S. and Walter, N.T. (2005) The Relationship between Selected Demographic Factors and the Level of Job Satisfaction of Extension Agents. Journal of Southern Agriculture Education Research, 55, 102-114.

[91] Lee, R. and Wilbur, E.R. (1985) Age, Education, Job Tenure, Salary, Job Characteristics, and Job Satisfaction: A Multivariate Analysis. Human Relations, 38, 781-791. http://dx.doi.org/10.1177/001872678503800806

[92] Huey, J.D. (2003) The Influence of Family Responsive Practices on Job Satisfaction, Organizational Commitment, and Intentions to Turnover for Working Women with Children. International Dissertation.

[93] Brown, G., Gardner, J., Oswald, A. and Qian, J. (2007) Does Wage Rank Affect Employees' Well-Being? Industrial Relations, 47, 355-389. http://dx.doi.org/10.1111/j.1468-232X.2008.00525.x

[94] Shields, M.A. and Ward, M. (2001) Improving Nurse Retention in the National Health Service in England: The Impact of Job Satisfaction on Intentions to Quit. Journal of Health Economics, 20, 677-701. http://dx.doi.org/10.1016/S0167-6296(01)00092-3

[95] Bender, K.A. and Heywood, J.S. (2006) Job Satisfaction of the Highly Educated: The Role of Gender, Academic Tenure and Comparison Income. Scottish Journal of Political Economy, 53, 253-279. http://dx.doi.org/10.1111/j.1467-9485.2006.00379.x

[96] Scott, M., Swortzel, K.A. and Taylor, W.N. (2005) The Relationships between Selected Demographic Factors and the 
Level of Job Satisfaction of Extension Agents. Journal of Southern Agricultural Education Research, 55, 102-115. http://pubs.aged.tamu.edu/jsaer/pdf/Vol55/55-01-102.pdf http://dx.doi.org/10.5032/jae.2005.03002

[97] Cano, J. and Miller, G. (1992) A Gender Analysis of Job Satisfaction, Job Satisfier Factors, and Job Dissatisfier Factors of Agricultural Education Teachers. Journal of Agricultural Education, 33, 40-46. http://dx.doi.org/10.5032/jae.1992.02040

[98] Colquitt, J., Greenberg, J. and Zapata-Phelan, C.P. (2005) What Is Organizational Justice? A Historical Overview. In: Greenberg, J. and Colquitt, J., Eds., Handbook of Organizational Justice, Lawrence Erlbaum Associates, Mahwah, 356.

[99] Goodman, P.S. and Friedman, A. (1971) An Examination of Adams' Theory of Inequality. Administrative Science Quarterly, 16, 271-288. http://dx.doi.org/10.2307/2391900

[100] Parker, C.P., Battes, B.B. and Christiansen, N.D. (1997) Support for Affirmative Action, Justice Perceptions, and Work Attitudes: A Study of Gender and Racial-Ethnic Group Differences. Journal of Applied Psychology, 82, 376-389. http://dx.doi.org/10.1037/0021-9010.82.3.376

[101] Cowherd, D.M. and Levine, D.I. (1992) Product Quality and Pay Equity between Lower-Level Employees and Top Management: An Investigation of Distributive Justice Theory. Administrative Science Quarterly, 37, 302-320. http://dx.doi.org/10.2307/2393226

[102] Pfeffer, J. and Langton, N. (1993) The Effect of Wage Dispersion on Satisfaction, Productivity, and Working Collaboratively: Evidence from College and University Faculty. Administrative Science Quarterly, 38, 382-407. http://dx.doi.org/10.2307/2393373

[103] Cropanzano, R. and Folger, R. (1991) Procedural Justice and Worker Motivation. In: Steers, R.M. and Porter, L.W., Eds., Motivation and Work Behavior, 5th Edition, McGraw-Hill, New York, 131-143.

[104] Skarlicki, D.P., Folger, R.G. and Tesluk, P. (1999) Personality as a Moderator in the Relationship between Fairness and Retaliation. Academy of Management Journal, 42, 100-108. http://dx.doi.org/10.2307/256877

[105] Mossholder, K.W., Bennett, N. and Martin, C.L. (1998) A Multilevel Analysis of Procedural Justice Context. Journal of Organizational Behavior, 19, 131-141. http://dx.doi.org/10.1002/(SICI)1099-1379(199803)19:2<131::AID-JOB878>3.0.CO;2-P

[106] Konovsky, M.A. and Cropanzano, R. (1991) Perceived Fairness of Employee Drug Testing as a Predictor of Employee Attitudes and Job Performance. Journal of Applied Psychology, 76, 698-707. http://dx.doi.org/10.1037/0021-9010.76.5.698

[107] Taylor, M.S., Tracy, K.B., Renard, M.K., Harrison, J.K. and Carroll, S.J. (1995) Due Process in Performance Appraisal: A Quasi-Experiment in Procedural Justice. Administrative Science Quarterly, 40, 495-523. http://dx.doi.org/10.2307/2393795

[108] Cobb, A.T. and Frey, F.M. (1996) The Effects of Leader Fairness and Pay Outcomes on Superior/Subordinate Relations. Journal of Applied Social Psychology, 26, 1401-1426. http://dx.doi.org/10.1111/j.1559-1816.1996.tb00078.x

[109] Nadler, D.A. and Lawler III, E.E. (2007) Motivation: A Diagnostic Approach. In: Osland, J.S., Turner, M.E., Kolb, D.A. and Rubin, I.M., Eds., The Organizational Behavior Reader, 8th Edition, Pearson Prentice Hall, Upper Saddle River, 171-180.

[110] Organ, D.W. (1988) Organizational Citizenship Behavior: The Good Soldier Syndrome. Lexington, Lexington Books.

[111] Leventhal, G.S., Karuza, J. and Fry, W.R. (1980) Beyond Fairness: A Theory of Allocation Preferences. In: Milkula, G., Ed., Justice and Social Interaction, Springer-Verlag, New York, 167-218.

[112] Greenberg, J. (1986) Determinants of Perceived Fairness of Performance Evaluations. Journal of Applied Psychology, 71, 340-342. http://dx.doi.org/10.1037/0021-9010.71.2.340

[113] Sheppard, B., Lewicki, R. and Minton, J. (1992) Organizational Justice: The Search for Fairness in the Workplace. Lexington Books, New York.

[114] Iqbal, K. (2013) Determinants of Organizational Justice and Its Impact on Job Satisfaction: A Pakistan Base Survey. International Review of Management and Business Research, 2, 48-56.

[115] Sareshkeh, S.K., Ghaziani, F.G. and Tayebi, S.M. (2012) Impact of Organizational Justice Perception on Job Satisfaction and Organizational Commitment: The Iranian Sports Federation Perspective. Annals of Biological Research, 3, 4229-4238.

[116] Elovainio, M., Kivimaki, M. and Vahtera, J. (2002) Organizational Justice: Evidence of a New Psychosocial Predictor of Health. American Journal of Public Health, 92, 105-108. http://dx.doi.org/10.2105/AJPH.92.1.105

[117] Shapiro, D.L., Buttner, E.H. and Barry, B. (1994) Explanations: What Factors Enhance Their Perceived Accuracy. Organizational Behavior and Human Decision Processes, 58, 346-368. http://dx.doi.org/10.1006/obhd.1994.1041 
[118] Mowday, R.T., Steers, R.M. and Porter, L. (1979) The Measurement of Organizational Commitment. Journal of Organizational Behavior, 14, 224-247. http://dx.doi.org/10.1016/0001-8791(79)90072-1

[119] Brayfield, A.H. and Rothe, H.F. (1951) An Index of Job Satisfaction. Journal of Applied Psychology, 35, 307-311. http://dx.doi.org/10.1037/h0055617

[120] Judge, T.A., Ilies, R. and Scott, B.A. (2006) Work-Family Conflict and Emotions: Effects at Work and at Home. Personnel Psychology, 59, 779-814. http://dx.doi.org/10.1111/j.1744-6570.2006.00054.x

[121] Judge, T.A., Bono, J.E. and Locke, E.A. (2000) Personality and Job Satisfaction: The Mediating Role of Job Characteristics. Journal of Applied Psychology, 85, 237-249. http://dx.doi.org/10.1037/0021-9010.85.2.237

[122] Nifadkar, R.S. and Dongre, A.P. (2014) To Study the Impact of Job Satisfaction and Demographic Factors on Organizational Commitment among Girls' College, Pune. India Journal of Business Management \& Social Sciences Research, 3, 1-8.

[123] Chughtai, A.A. and Zafar, S. (2006) Antecedents and Consequences of Organizational Commitment among Pakistani University Teachers. Applied HRM Research, 11, 39-64.

[124] Yoon, J.K. (1996) Fairness Issues and Job Satisfaction among Korean Employees: The Significance of Status and Procedural Justice in Work Orientation. Social Justice Research, 9, 121-143. http://dx.doi.org/10.1007/BF02198076

[125] Rivai, H.A. (2005) An Empirical Test of the Impacts of Organizational Justice, Job Satisfaction and Commitment on Turnover Intent and Organizational Citizenship Behavior. The Asian Academy of Applied Business, 2, 278-292.

[126] Imberman, M.D. (2009) Organizational Change and Organizational Justice: Assessing the Impact on Organizational Commitment, Change Oriented Organizational Citizenship Behaviour, and Attitude toward Future Change. PhD Dissertation, Alliant International University, Los Angeles.

[127] Lavelle, J.J., Rupp, D.E. and Brockner, J. (2007) Taking a Multifoci Approach to the Study of Justice, Social Exchange, and Citizenship Behavior: The Target Similarity Model. Journal of Management, 33, 841-866. http://dx.doi.org/10.1177/0149206307307635

[128] Wayne, S.J., Shore, L.M., Bommer, W.H. and Tetrick, L.E. (2002) The Role of Fair Treatment and Rewards in Perceptions of Organizational Support and Leader-Member Exchange. Journal of Applied Psychology, 87, 590-598. http://dx.doi.org/10.1037/0021-9010.87.3.590 